\title{
Perkembangan Yoghurt Susu Kedelai
}

\author{
Sarah Amelia Nur Wahidah Al Falah, ${ }^{\mathrm{a}, 1, *}$, Shinta Maharani ${ }^{\mathrm{a}, 2}$ \\ ${ }^{a}$ Universitas Pendidikan Indonesia, J1. Setiabudhi No. 229, Isola, Kec. Sukasari, Bandung, 40154, Indonesia \\ ${ }^{1}$ sarahamelia14@upi.edu*; ${ }^{2}$ shinta.maharani@upi.edu \\ *penulis korespondensi
}

\begin{abstract}
Yogurt is a fermented dairy product that can be made from high-protein vegetable ingredients, one of which is soy. Soy milk yogurt has a high nutritional content that is very beneficial for the body. Today, new innovations emerged from the development of soy yogurt, one of which is by adding flavor variations from fruits, corn, and natural sweeteners. The addition of flavor variations in soy yogurt aims to add sweetness and further increase its nutritional content. This results in changes in the sensory characteristics of soy yogurt. The purpose of this study was to find out the characteristics of soy yogurt with a variety of flavors. The method used in this research is literature review. The result of this study is the addition of other compositions affecting the color, aroma, $\mathrm{pH}$, and syneresis of soy yogurt.
\end{abstract}

Keywords: corn, fruits, natural sweetener, soy yogurt

\begin{abstract}
ABSTRAK
Yoghurt merupakan suatu produk susu fermentasi yang dapat dibuat dari bahan nabati tinggi protein salah satunya kedelai. Yoghurt susu kedelai memiliki kandungan gizi cukup tinggi yang sangat bermanfaat bagi tubuh. Dewasa ini, muncul inovasi baru dari perkembangan yoghurt kedelai salah satunya dengan penambahan variasi rasa dari buah-buahan, jagung, serta pemanis alami. Penambahan variasi rasa pada yoghurt kedelai bertujuan untuk menambahkan rasa manis serta lebih meningkatkan kandungan gizinya. Hal tersebut mengakibatkan terjadinya perubahan karakteristik sensorik yoghurt kedelai. Tujuan dari penelitian ini adalah untuk mengetahui karakteristik dari yoghurt kedelai dengan berbagai variasi rasa. Metode yang digunakan dalam penelitian ini adalah literature review. Hasil dari penelitian ini adalah penambahan komposisi lain berpengaruh terhadap warna, aroma, $\mathrm{pH}$, dan sineresis yoghurt kedelai.
\end{abstract}

Kata kunci: buah-buahan, jagung, pemanis alami, yoghurt kedelai

\section{Pendahuluan}

Susu kedelai merupakan produk yang berasal dari ektrak biji kedelai yang memiliki nilai gizi yang tinggi yang diperlukan oleh tubuh sepeti kandungan serat, asam lemak tak jenuh, serta protein yang tinggi yang baik untuk kesehatan. Susu kedelai mejadi alternatif pengganti susu sapi bagi penderita alergi susu sapi atau yang tidak menyukai susu sapi, bagi vegetarian, orang yang tidak mampu membeli susu atau daging sebagai sumber protein paling mahal, serta cocok untuk dikomsumsi semua golongan usia (Picauly et al., 2018). Namun, karena susu kedelai mengandung nutrisi dan air yang sangat tinggi, sehingga susu kedelai termasuk ke dalam bahan yang mudah rusak karena lingkungannya sangat menguntungkan bagi mikroorganisme (Frida, et al., 2013). Oleh karena itu, agar 
menjaga kualitas susu kedelai diperlukan teknologi pengolahan untuk memperpajang umur simpan, salah satunya dengan melakukan fermentasi.

Banyak upaya untuk menghasilkan produk susu kedelai seperti yoghurt kedelai, es krim kedelai, keju kedelai, dan sejenisnya. Berdasarkan data dari Peraturan BPOM Nomor 30 Tahun 2018 tentang Angka Konsumen Pangan jumlah penduduk Indonesia yang mengonsumsi minuman berbasis susu fermentasi sebanyak $155 \mathrm{~g} /$ orang/hari. Yoghurt merupakan produk susu sapi atau susu kedelai nabati yang difermentasi menggunakan bakteri Lactobacillus bulgaricus dan Streptococcus thermophilus, atau bakteri asam laktat lainnya (Oyeniyi, et al,. 2014). Yoghurt susu kedelai telah banyak diteliti secara ekstensif (Tabel 1.1). Produk susu kedelai yang di fermentasi memiliki manfaat dari sudut pandang ekonomi dan gizi, karena produk ini mengandung protein yang lebih tinggi tetapi biaya produksi lebih rendah jika dibandingkan dengan yoghurt susu biasa (Denkova, et al., 2005).

Tabel 1.1 Perkembangan Penelitian Yoghurt Kedelai

\begin{tabular}{clll}
\hline No & $\begin{array}{c}\text { Kelompok Penambahan } \\
\text { Variasi Rasa }\end{array}$ & \multicolumn{1}{c}{ Sampel } & \multicolumn{1}{c}{ Referensi } \\
\hline 1. & Buah-buahan & Strawberry soy-yoghurt & (Osundahunsi, et al. 2007) \\
& & $\begin{array}{l}\text { Vanilla soy-yoghurt } \\
\text { Plain soy-yoghurt }\end{array}$ & (Labiba, et al., 2020) \\
& & Orange soy-yoghurt & (Kurniawati, 2015) \\
& & Pineapple fruit soy-yoghurt & (Gutema, 2013) \\
& & Pawpaw fruit soy-yoghurt & (Othman, et al., 2019) \\
& & Banana soy-yoghurt & (Oyeniyi, et al., 2014) \\
& & Corn soy-yoghurt & (Lestiyani, et al., 2014) \\
& & Honey soy-yoghurt & (Koohkan, et al., 2017) \\
\hline
\end{tabular}

Konsumsi yoghurt susu kedelai tidak banyak yang menyukai dikarenakan adanya rasa tidak enak, hal ini disebabkan dari kandungan kacang kedelai seperti asam sulfat, oligosakarida, penghambat trypsin, dan sebagainya (Jayalalitha, et al,. 2015). Namun, seiring perkembangan zaman banyak penelitian mengenai penambahan variasi rasa pada olahan youghurt susu kedelai. Dengan penambahan bahan lain seperti buah-buah, serealia, dan pemanis alami (madu) dapat menghilangkan rasa khas susu kedelai serta menimbulkan rasa manis sehingga akan lebih menarik untuk dikonsumsi. Penambahan variasi aneka rasa pada yoghurt kedelai akan berpengaruh terhadap karakteristik fisik yoghurt susu kedelai. Tujuan dari penelitian ini adalah untuk membandingkan karakteristik fisik dari yoghurt kedelai seperti aroma, sineresis, rasa, tekstur, dan $\mathrm{pH}$ dengan penambahan variasi rasa seperti buah-buahan, serealia, serta pemanis alami.

\section{Metode Penelitian}

Metode yang digunakan dalam penelitian ini adalah literature review dengan pengambilan data dari berbagai sumber yang relevan. Tahapan penelitian terdiri dari empat proses yaitu searching, critiquing, synthesizing, dan writing (Baker, 2016). Jurnal digunakan dalam literature review didapatkan melalui database penyedia jurnal nasioanal 
maupun internasional seperti science direct dan google scholar. Penulis menuliskan kata kunci dan mendapatkan 8.423 artikel ditemukan, penulis memilih sendiri artikel sesuai dengan judul dan abstrak yang memberikan data mengenai yoghurt kedelai-buah, yoghurt kedelai-jagung, dan yoghurt kedelai-pemanis alami.

\section{Hasil dan Pembahasan}

Yoghurt kedelai memiliki nilai pH normal sebesar 4-6,99 (Purwati, et al., 2008; Fatmawati, et al., 2013) yang diakibatkan dari pertambahan kadar asam yang dihasilkan oleh Lactobacillus bulgaricus dan Streptococcus thermophilus (Fatmawati, et al., 2013). Nilai viskositas pada yoghurt susu kedelai mengalami kenaikan pada setiap formula yang menyebabkan terjadinya peningkatan total padatan pada yoghurt susu kedelai. Yoghurt susu kedelai memiliki rasa khas dan sedikit asam (Kurniawan, 2018). Dengan berkembanganya pengetahuan dan teknologi para peneliti melakukan berbagai inovasi pada produk yoghurt susu kedelai, salah satunya dengan menambahkan variasi rasa yang bertujuan untuk menarik perhatian masyarakat mengonsumsi yoghurt susu kedelai dan untuk meningkatkan nilai gizi yang terkandungnya. Beberapa penambahan komposisi lain pada yoghurt susu kedelai diantaranya yoghurt kedelai rasa buah-buahan, yoghurt kedelai dengan rasa jagung, dan yoghurt kedelai dengan penambahan pemanis alami.

\subsection{Yoghurt Kedelai dengan Penambahan Buah-buahan}

Penambahan buah-buahan pada yoghurt kedelai untuk menutupi rasa khas susu kedelai dan bertujuan untuk mendapatkan nilai gizi maksimum. Rasio perbandingan biasanya diatur menurut peraturan yang diberikan oleh setiap negara. FAO merekomendasikan yoghurt kedelai buah-buahan antara 5-15\% kandungan buah-buahan yang ditambahkan (Jayalalitha, et al,. 2015). Rasa "beany" menimbulkan ketidaknyamanan rasa dari susu kedelai yang tidak disukai, sehingga perlu adanya komposisi lain seperti buah-buahan untuk menambahkan cita rasa yoghurt (Kale, et al., 2012; Grace, et al., 2019) serta dapat meningkatkan nilai gizi yang terkandung (Kumar, 2014). Pada saat ini terdapat banyak yoghurt kedelai yang dikombinasikan dengan berbagai rasa jus buah (Rostango, et al., 2007).

Berdasarkan penelitian yang dilakukan oleh Nabulsi, et al. (2014) menunjukkan bahwa yoghurt dengan penambahan rasa jeruk dan stroberi dinilai dari aroma dan rasa jauh lebih diminati dibandingkan dengan yoghurt kedelai biasa. Selain itu, Yoghurt kedelai mangga banyak diminati dengan rasio perbandingan 7,1\% buah mangga, 14,7\% susu kedelai, dan 78,2\% susu kerbau (Sakhale, et al., 2012; Bedani, et al., 2014).

Dalam produk makanan seperti yoghurt, nilai $\mathrm{pH}$ merupakan salah satu faktor penting untuk menentukan tingkat ketahanan terhadap pertumbuhan mikroorganisme perusak selama proses penyimpanan dan distribusi. Penambahan variasi rasa buah-buahan dapat mengubah $\mathrm{pH}$ dan tingkat keasaman yoghurt (Osman \& Razig, 2010). Tabel 2 menunjukkan bahwa nilai $\mathrm{pH}$ pada yoghurt kedelai dengan aneka rasa buah-buahan berkisar antara 4,4-4,7 hal ini serupa dengan penelitian yang dilakukan oleh Grace, et al. (2019). Perubahan kadar asam $\mathrm{pH}$ dan asam laktat yang terkandung menunjukkan bahwa aktivitas stater tidak sepenuhnya ditahan meskipun menurun secara drastis (Osundahunsi, et al., 2007; Nabulsi, et al., 2014) (Tabel 3.1). Selain itu, padatan total dalam produk 
pangan susu dan yoghurt yang mengandung protein, karbohidrat, lemak, vitamin, serta mineral yang tidak dapat larut dalam air (Grace, et al., 2019). Peningkatan padatan total menjadi sebab ternjadinya tingginya asam laktat yang terkandung (Susanti, 2005).

Tabel 3.1 pH, Kandungan Asam Laktat, dan Padatan Terlaurt

\begin{tabular}{lccc}
\hline \multicolumn{1}{c}{ Produk* } & $\mathrm{pH}$ & Asam Laktat $(\%)$ & Padatan Terlaurt \\
\hline Strawberry soy-yoghurt & 4,6 & 0,9 & 26,4 \\
Vanilla soy-yoghurt & 4,7 & 0,7 & 23,9 \\
Plain soy-yoghurt & 4,7 & 0,8 & 18,4 \\
Orange soy-yoghurt & 4,7 & 0,8 & 22,4 \\
Orange fruit soy-yoghurt & 4,4 & 1,08 & 25,9 \\
Pineapple fruit soy-yoghurt & 4,4 & 1,08 & 27,9 \\
Pawpaw fruit soy-yoghurt & 4,4 & 1,06 & 26,3 \\
\hline
\end{tabular}

Sumber: Osundahunsi, et al. (2007)

\subsection{Yoghurt Kedelai dengan Penambahan Jagung}

Susu kedelai jagung merupakan susu campuran antara ektraksi kedelai dan jagung. Produksi susu berbasis kedelai telah dikembangkan untuk mengatasi masalah intoleransi laktosa dan lemak jenuh susu sapi, serta sebagai sumber protein yang murah. Oleh karena itu, dilakukan penggabungan antara kedelai dan jagung untuk menghasilkan susu kedelai jagung yang bergizi (Kolapo, et al., 2008). Rendahnya kandungan aflatoxin berpotensi menjadi bahan utama pembuatan yoghurt susu nabati, hal tersebut sesuai dengan penelitian yang dilakukan oleh Makanjuola (2012) dengan mengembangkan yoghurt susu nabati yaitu yoghurt susu kedelai dan yoghurt jagung. Lactobacillus bulgaricus dan Strepcoccus thermophilus telah digunakan sebagai stater untuk memproduksi yoghurt susu kedelai jagung (Supavititpatana, et al., 2010). Pembuatan yoghurt susu kedelai dengan penambahan jagung sebagi pemberi rasa manis, maka akan mempengaruhi karakteristiknya yaitu $\mathrm{pH}$, tingkat keasaman, sineresis, aroma, dan rasa (Lestiyani, et al., 2014; Makanjuola, et al., 2012; Shrestha, et al., 2018).

Pada rasio komposisi yang berbeda antara kacang kedelai dan jagung manis mendapatkan pH pada kisaran 4,539 dan 6,7 (Lestiyani, et al., 2014). Yoghurt susu kedelai dengan total solid 13,15\%, pH 6,7, serta tingkat keasaman 0,20\% menyatakan adanya variasi pada hasil pembuatannya antara air yang digunakan pada saat pembuatan susu kedelai (Pyo, et al., 2005; Bhattarai, et al., 2008). Sifat sensorik sampel yoghurt kedelai jagung memiliki warna kuning yang dihasilkan dari pigmen xanthophll (karoten) jagung (Makanjuola, 2012). Kemudian yoghurt kedelai jagung memiliki viskositas cukup tinggi serta tidak ada berbeda yang signifikan dengan yoghurt pada umumnya (Smoothie, 2008; Makanjuola, 2012). 


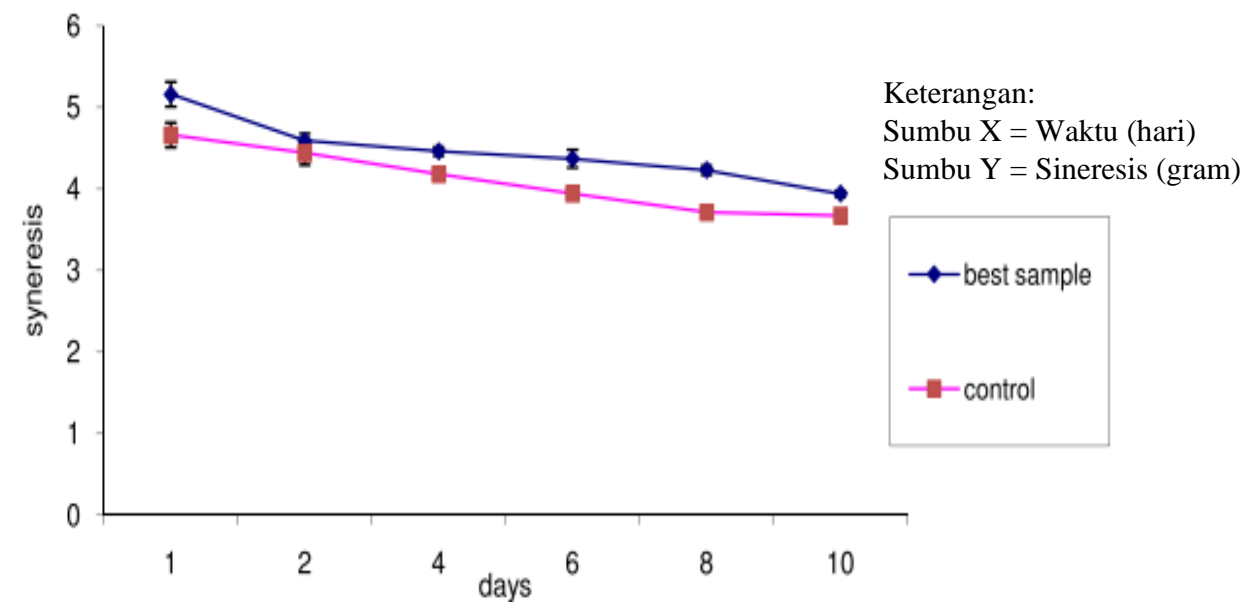

Gambar 3.1 Efek Waktu Penyimpanan dengan Sineresis (Shrestha, et al., 2018)

Perbandingan efek sineresis pada penyimpanan yoghurt kedelai jagung dengan lamanya waktu penyimpanan adalah signifikan. Sineresis meningkat sepanjang periode penyimpanan pada kedua sampel (Gambar 3.1). Laju peningkatan dalam sampel susu jagung jauh lebih rendah daripada sampel kontrol (Shrestha, et al., 2018). Dalam sampel yoghurt yang menggunakan stabilizer dan kontrol, sineresis meningkat dengan lamanya waktu penyimpanan. Namun akan lebih rendah jika dibandingkan dengan sampel yang tidak menggunakan stabilizer (Bhattarai, et al., 2008; Shrestha, et al., 2018). Oleh karena itu, penggunaan stabilitator dapat meningkatkan dan memberikan viskositas yang lebih stabil (Lee \& Lucey, 2010).

\subsection{Yoghurt Kedelai dengan Penambahan Bahan Pemanis Alami}

Penambahan komposisi variasi rasa pada yoghurt kedelai pada umumnya untuk membuat yoghurt lebih enak dimakan (Pinheiro et al., 2005; Remirez, et al., 2013).

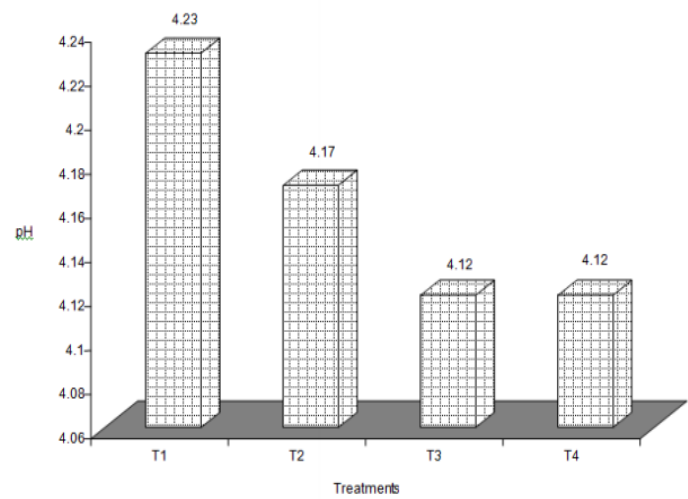

Gambar 3.2 Nilai rata-rata $\mathrm{pH}$

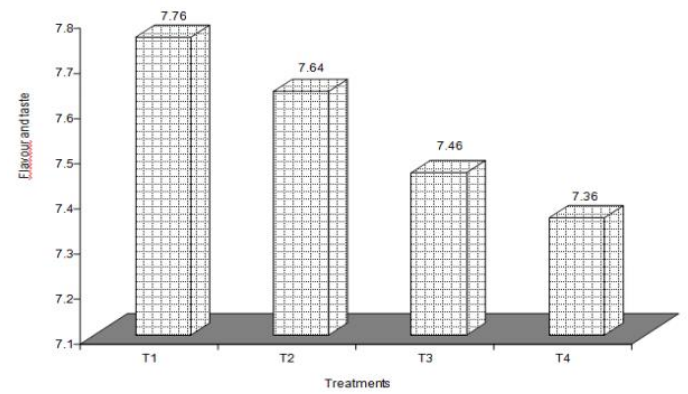

Gambar 3.3 Nilai rata-rata rasa

\section{Keterangan:}

$\mathrm{T} 1$ = Perlakuan dengan penambahan madu pada $\mathrm{pH}$ 4,23

T2 = Perlakuan dengan penambahan madu pada $\mathrm{pH} 4,17$

$\mathrm{T} 3$ = Perlakuan dengan penambahan madu pada $\mathrm{pH}$ 4,12

$\mathrm{T} 4=$ Perlakuan dengan penambahan madu pada $\mathrm{pH}$ 4,12

Sumber: Rashid \& Thakur (2012) 
Komposisi rasa manis yang biasanya ditambahkan adalah sukrosa, tetapi konsumen lebih memprioritaskan produk yoghurt dengan rasa manis alami (Sharma, 2014) hal tersebut terjadi karena munculnya kekhawatiran akan kesejahteraan dan kesehatan sehingga masyarakat beralih menggunakan pemanis alami (Moure, et al., 2006; Simonsohn, 2012; Hill, et al., 2014; Miele, et al., 2017). Penambahan pemanis alami mengakibatkan adanya perubahan karakteristik sensorik pada yoghurt kedelai (Krisnaningsih \& Dyah, 2015).

Pada gambar 3.2 menunjukkan bahwa nilai $\mathrm{pH}$ terus menurun jika terus meningkatkan komposisi madu. Hal tersebut dikarenakan terjadinya peningkatan derajat sebagai keasaman dan $\mathrm{pH}$ yang berbanding terbalik (Rashid \& Thakur, 2012), sejalan dengan penelitian yang dilakukan oleh Yang et al. (2014) yang menambahkan erythinol dan IMO (Isomalto-oligosakarida). Gambar 3.3 menunjukkan bahwa semakin banyak bahan pemanis yang ditambahkan maka semakin hilang rasa khas kedelai di dalam yoghurt (Rashid \& Thakur, 2012). Rata-rata sineresis yang dihasilkan pada sampel keseluruhan adalah $23 \pm$ 1,7\% (Miele, et al., 2017), tetapi penambahan pemanis alami tidak signifikan mempengaruhi $(\mathrm{a}=0,05)$ tingkat sineresis pada sampel yoghurt setelah disimpan semalaman (Miele, et al., 2017; Krisnaningsih \& Dyah, 2015).

\section{Kesimpulan}

Perkembangan teknologi dan pengetahuan mendorong para peneliti untuk menghasilkan suatu produk pangan yang memiliki nilai gizi tinggi. Yoghurt kedelai kurang disukai karena memiliki rasa yang tidak enak yang dihasilkan pada saat proses fermentasi susu kedelai. Penambahan komposisi lain seperti buah-buahan, jagung, dan pemanis alami mampu menarik minat dengan rasa manis yang bervariasi serta dapat meningkatkan nilai gizinya. Selain itu, penambahan variasi rasa pada yoghurt kedelai berpengaruh terhadap karakteristik dari produk yang dihasilkan. Penambahan buah-buahan jagung, dan pemanis alami berpengaruh terhadap rasa, sineresis, $\mathrm{pH}$, dan warna dari yoghurt kedelai yang dihasilkan.

\section{Ucapan Terima Kasih}

Penulis mengucapkan terima kasih kepada dosen-dosen serta rekan-rekan mahasiswa Program Studi Pendidikan Teknologi Agroindustri yang selalu memberikan dukungan baik moril maupun materi sehingga penulis dapat menyelesaikan artikel review ini.

\section{Pustaka}

Badan Pengawas Obat dan Makanan. 2018. Pengaturan Badan Pengawas Obat dan Makanan Nomor 30 Tahun 2018 tentang Angka Konsumsi Pangan.

Baker, J. D. 2016. The Purpose, Process, and Methods of Writing a Literature Review. AORN Journal. Volume 103: 265-269.

Bedani R., Antonio D. S. V., Elizeu A. R. 2014. Tropical Fruit Pulps Decreased Probiotic Survival to in Vitro Gastrointestinal Stress in Synbiotic Soy Yoghurt With Okara During Storage. LWT-Food Science and Technology. Volume 55: 436-443. 
Bhattarai, Nirmala, Pradhananga, Mahalaxmi, Mishra, Shyam K. 2008. Effects of Various Stabilizers on Sensorial Quality of Yoghurt. Sunsari Technical College Journal. Volume 2(1): 7-12.

Denkova Z. R., I. D. Murgov. 2005. Soy Milk Yoghurt. Biotechnol \& Biotechnol Eq. Volume 19(1): 193-195.

Fatmawati U., Faisal I. P., Mega S. T. A., Ardiyanti N. U. 2013. Karakteristik Yoghurt yang Terbuat dari Berbagai Jenis Susu Dengan Penambahan Kultur Campuran Lactobacillus bulgaricus dan Streptococcus thermophillus. BIOEDUKASI. Volume 6(2): 1-9.

Frida D. A., Ririen P. 2013. Pengaruh Jenis Komoditi Kedelai (Organik dan Anorganik) dan Suhu Penyimpanan Terhadap Umur Simpan Susu Kedelai. Jurnal Ilmu-ilmu Pertanian. Volume 7(2): 98-108.

Grace A. T., Rani, D. P., Septriyanto D. 2019. Antioxidant Activities of Soy Yoghurt Production in Combination with Red Fruit (Pandanus conoideus Lam.). Journal Food Life Sci. Volume 3(2): 65-73.

Gutema, B. 2013. Effect of Supplementation of Pineapple Juice on the Sensory Characteristics of Soy-Yoghurt. Thesis. School of Nutrition, Food Science and Technology, Hawassa University.

Hill S. E., M. L. Prokosh, A. Morin, C. D. Rodeheffer. 2014. The Effect of Non-Caloric Sweeteners on Cognition, Choice, and Post-consumption Satisfaction. Appective. Volume 83: 82-88.

Jayalalitha V., Manoharan A.P., Balasundaran B., Elango A. 2015. Formulation of Value Enriched Yoghurt with Soy Milk and Mango Pulp. Journal of Nutrition \& Food Science. Volume 5(6) : 1-4.

Kale R. V., Pandhare G. R., Satwase A. N., Goswami D. 2012. Effect of Different Concentration of Orange Juice on Quality Characteristics of Soya Milk Blended Beverage. Journal of Food Processing \& Technology. Volume 3(2): 1-5.

Kolapo A. L., Oladimeji G.R. 2008. Production and Quality Evaluation of Soy Corn Milk. $J$ Appl Biosci. Volume 1: 40-45.

Koohkan, S., David H. M., Aloys B. 2017. The Effect of a Soy-Yoghurt Honey Product on Excess Weight and Related Health Risk Factors-A Review. Jurnal of Nutritional Health \& Food Science. Volume 5(2): 1-10.

Krisnaningsih A. T. N., Dyah L. Y. 2015. Improving The Quality of The Yoghurt with The Addition of Honey. Proceedings. Universitas Halu Oleo, Sulawesi Tenggara.

Kumar D., S. N. Thakur. 2014. Sensory and Physico-chemical Analysis of Banana Based Probiotic Soy Yoghurt Toward Consumer's Acceptance. International Journal of Scientific Research. Volume 3(6): 96-98.

Kurniawan J. 2018. Uji Organoleptik Yoghurt Berbahan Baku Susu Kacang Kedelai Berdasarkan Lama Waktu Fermentasi. National Conference of Creative Industry: Sustainable Tourism Industry of Economic Development. Universitas Bunda Mulia, Jakarta.

Kurniawati, E. G. 2015. Kualitas Soyghurt dengan Penambahan Inokulan Yakult dan Yoghurt. Artikel Ilmiah. Universitas Muhammadiyah Surakarta. 
Labiba, N. M., Avliya Q. M., Nanang, N. 2020. Pengembangan Soyghurt (Yoghurt Susu Kacang Kedelai) sebagai Minuman Probiotik Tinggi Isoflavon. AGIKMI \& Universitas Airlangga. Halaman 244-249.

Lee, W. J., \& Lucey, J. A. 2010. Formation and Physical Properties of Yoghurt. AsianAust. J. Anim. Sci. 1127-1136.

Lestiyani, A. D., Thomas I. P. S., Ignatius S. 2014. Characteristics of Soy Corn Yogurt. Journal of Food \& Nutritional Disorders. Volume 3(1): 2-4.

Makanjuola O. M., 2012. Production and Quality Evaluation of Soy-Corn Yoghurt. Advance Journal of Food Science and Technology. Volume 4: 130-134.

Miele N. A., Erliza K. C., Giuseppe B., Serena L., Paolo M., Rosella M., Silvana C. 2017. Rheological and Sensory Performance of a Protein-Based Sweetener (MNEI), Sucrose, and Aspartame in Yoghurt. J. Dairy Sci. Volume 100: 9539-9550.

Moure A., P. Gullon, H. Dominguez, J. C. Parajo. 2006. Advances in the Manufacture, Purification and Applications of Xylooligosaccharides as Food Additives and Nutraceuticals. Process Biochem. Volume 41: 1913-1923.

Nabulsi A., Reyad S., Tareq O., Mahmoud A., Amin O., Saddam A., Aisha A., Richard H. 2014. Sensory Evaluation of Flavored Soy Milk-Based Yogurt: A Comparison Between Jordania and Malaysia Consumers. Journal of Food Science and Engineering. Volume 4: 27-35

Osman M. M. D., Razig K. A. A. 2010. Quality Attributes of Soy-Yoghurt During Storage Period. Pakistas Journal of Nutrition. Volume 9(11): 1088-1093.

Osundahunsi O. F. D. Amosu, B. O. T. Ifesan. 2007. Quality Evaluation and Acceptability of Soy-yoghurt with Different Colours and Fruit Flavours. American Journal of Food Technology. Volume 2(4): 273-380.

Othman N., Hazren A., Hamid, Suleiman N. 2019. Physicochemical Properties and Sensory Evaluation of Yoghurt Nutrionally Enriched with Papaya. Food Research. Volume 3(6): 791-797.

Oyeniyi A. O., Aworh O.C., Olaniyan J.O. 2014. Effect of Flavourings on Quality and Consumer Acceptability of Soy-Yoghurt. IOSR Journal of Evironmental Science, Technology. Volume 8(1): 38-44.

Picauly P., Talahatu P., P. Mailoa M.. 2018. Pengaruh Penambahan Air Pada Pengolahan Susu Kedelai. Jurnal Teknologi Pertanian. Volume 4(1): 8-13.

Pinheiro M. V. S., M. N. Oliveira, A. L. B. Penna, A. Y. Tamime. 2005. The Effect of Different Sweeteners in Low-calorie Yoghurt: A review. Int. J. Dairy Technol. Volume 58: 193-199.

Purwati H., Hodiana I., Aylianawati, Felycia E. S. 2008. Pengaruh Waktu Simpan Terhadap Kualitas Soyghurt dengan Penambahan Susu Bubuk. Widya Teknik. Volume 7(2) 134-143.

Pyo, Y. H., Lee T. C. Lee Y.C. 2005. Enrichment of Bioactive Isoflavones in Soymilk Fermented with I²-Glucosidase-Producing Lactic Acid Bacteria. Food Research International. Volume 38(5): 551-559.

Rasyid A., Er. S. N. Thakur. 2012. Studies on Quality Parameters of Set Yoghurt Prepared By the Addition of Honey. International Journal of Scientific and Research Publications. Volume 2(9): 1-10. 
Remirez-Sucre M. O., J. F. Velez-Ruiz. 2013. Physcochemical, Rheological and Stability Characterization of a Caramel Flavored Yoghurt. Food Sci Technol. Volume 51: 233-241.

Rostango M. A., Palma M., Barroso C. G. 2007. Ultrasound-assisted Extraction of Isoflavones From Soy Beverages Blended With Fruit Juices. Analytica Chimica Acta. Volume 597: 265-272.

Sakhale B. K., V. N. Pawar, R. C. Ranveer. 2012. Studies on Development of Soymilk Based Manggo RTS Beverage. Electronical Journal of Enviromental, Agricultural and Food Chemistry. Volume 11: 523-528.

Sharma R. 2014. Market Trends in Yoghurt Products. Dairy Innovation Australia Limited. June 3, 2014. Dairy Australia/NCDEA Webinar.

Shrestha S. L., Ram S. Y. 2018. Preparation and Quality Evaluation of Soy Corn Yoghurt. Himalayan Journal of Science and Technology. Volume 2: 102-107.

Simonsohn B. 2012. Stevia il Dolcificante Naturale. Techniche Nuove, Milan, Italy.

Smoothie Recipe. 2006. Soya. Information About Soy and Soya Product.

Supavititpatana P., Wirjantoro T.I., Raviyan R. 2010. Characteristics and Shelflife of Corn Milk Yoghurt. CMU J Nat Sci. Volume 9: 133-150.

Susanti D. 2005. Pembuatan Es Puter Yoghurt Kedelai dengan Penambahan Probiotik Lactobacillus achidophilus dan Bifldobacterium bifldum. Skripsi. Fakultas Teknologi Pertanian. Institut Pertanian Bogor, Bogor. 